\title{
Learning Trigonometry Using GeoGebra Learning Module: Are Under Achiever Pupils Motivated?
}

\author{
Muhammad Hafizhuddin Abdul Rahman ${ }^{a *}$, Marzita Puteh ${ }^{b}$ \\ ${ }^{a}$ Bahagian Tajaan Pendidikan, Kementerian Pendidikan Malaysia, Bangunan Mustapha Kamal, Jalan Usahawan 1, 63000, Cyberjaya \\ bJabatan Matematik, Fakulti Sains dan Matematik, Kampus Sultan Azlan Shah, Universiti Pendidikan Sultan Idris, 35900 Tanjung Malim \\ *Corresponding author: marzita@fsmt.upsi.edu.my
}

\begin{abstract}
Under achiever pupils were found to have low motivation level in learning mathematics. Pupils avoid Trigonometry and consider this topic as tough for them to master. The objective of this research is to measure under achiever motivation level towards Teaching and Learning (T\&L) Trigonometry II topic using GeoGebra Learning Module (GLM). This research has used explanatory mixed methods which is survey and interview to answer the research questions. Pupils were exposed to GLM in Trigonometry II topics for a duration of two weeks. Motivation level are measured using questionnaire adapted from Instructional Material Motivational Scale (IMMS). Five pupils then were interviewed by the researcher to gauge pupils motivation towards GLM. Respondents are from 21 under achiever pupils from one intact class in Muar, Johor. Data analysis showed overall pupils' motivation level are high $(\mathrm{M}=4.16, \mathrm{SD}=.279)$. The level of motivation of pupils for each subscale in ascending order is the Confidence $(\mathrm{M}=3.92, \mathrm{SD}=.268)$, Relevant $(\mathrm{M}=4.07$, $\mathrm{SD}=.357)$, Attention $(\mathrm{M}=4.25, \mathrm{SD}=.320)$, and Satisfaction $(\mathrm{M}=4.50, \mathrm{SD}=.436)$. Girls are significantly motivated $[\mathrm{t}(19)=2,401, \mathrm{p}<0.05, \mathrm{r}=1.07]$ compared to boys in using GLM. Result from the interviews were found similar to the surveys result. Pupils were found to be attracted to self access learning concept and slider function in the learning process. It is recommended that mathematics teachers should use GeoGebra by developing learning module that combine mathematics dynamic software and written module to help under achiever pupils further improve their motivation in T\&L.
\end{abstract}

Keywords: Under Achiever; trigonometry; GeoGebra; motivation

(C) 2017 Penerbit UTM Press. All rights reserved

\subsection{INTRODUCTION}

Report from Program for International Student Assessment (PISA) 2012 showed 51.8\% of Malaysian pupils are from under achiever group (OECD, 2014). Focus should be given to this group of pupils considering Malaysians pupils low achievement in previous PISA assessment. Research found that excellent pupils did not need help in the form of ICT intervention to excel in mathematics compared to under achiever (Azura Ishak, Zakaria Kasa, Mohd Hasan Selamat, \& Bahaman Abu Samah, 2009). Previous researchers also showed pupils with low achievement in mathematics have lower motivation compared to excellent pupils (García \& Romero, 2009; OECD, 2014). There is strong needs to enhance under achiever Malaysian pupils motivation so that increase their performance in order to achieve developed nation by the year 2020 .

In learning mathematics, pupils sees mathematics as tough and mundane subject (Marzita Puteh \& Rohaidah Masri, 2006), irrelevance (Furner \& Berman, 2005), frustrated, not motivated and feel anxiety (Ignacio, Nieto, \& Barona, 2006). Negative perception such as anxiety, boredom, afraid, see mathematics as no relevance cause pupils to avoid learning mathematics (Escuder \& M. Furner, 2011). According to Noor Shah Saad \& Sazelli Abdul Ghani, (2010) pupils consider mathematics as following certain procedure told by teacher in order to answer questions and solve problems. This consideration led pupils to consider mathematics as static, non-structures, no connection with daily life, and various formula and procedure to remember to pass mathematics test (Sherman, 2011). Traditional T\&L are the main reason that contribute for this perception (Marzita Puteh \& Rohaidah Masri, 2006). In traditional T\&L, pupils' role were only limited to absorb all the information given by the teachers thus becoming passive partner in the process. Teacher-centered learning would cause pupils to easily get bored and pupils will associates mathematics with negative perception.

However, based on previous research, T\&L using dynamic mathematical software attract pupils' attraction and motivation (AbuObaidah et al, 2012; Ahmad Fauzi Mohd Ayub, Rohani Ahmad Tarmizi, Kamariah Abu Bakar, \& Wong, 2014; Al-A'ali, 2008). Researcher also found the use of GeoGebra in T\&L showed positive effects to pupils in term of perception (Praveen \& Leong, 2013; Ting, 2013) and motivation (Effandi Zakaria \& Lee, 2012; Mohd Zamri Abdullah, 2012). Teachers motivation are an important factor that would determine pupils succeed in mathematics (Mislina Atan, 2010). Good learning material should enhance not only pupils' achievement but also pupils' motivation (Kamariah, Ahmad Fauzi, Wong, \& Rohani, 2010). By using ICT, it can increase pupils' motivation to learn, easy to understand and provide better opportunities for exercises and enrichment activities (Ahmad Fauzi Mohd Ayub et al., 2014). A good learning material should have four characteristics which are (1) the knowledge acquired by the pupils formed by mapping the actions and thoughts of pupils; (2) social interaction between pupils in order to develop knowledge (Praveen \& Leong, 2013); (3) knowledge formed is the result of activities undertaken by the pupils themselves and (4) communication between teachers is not the source of the knowledge of pupils rather only as a 
guide for pupils to develop cognitive schemes (Noor Shah Saad \& Sazelli Abdul Ghani, 2010). The advantages from learning mathematics in constructivist way such as using GLM will make pupils think, understand, remember, confident, excited and improve social skills which in turn translates into better motivation.

Trigonometry is one of the important components in mathematics to master. This topic combines algebra, geometry and graphical reasoning and the basis of the calculus, physics, architecture, surveying, and engineering. Trigonometry was considered among the topics which are difficult to master by pupils (Demir, 2012; Gur, 2009; Jaworski, 2010; Moore, 2012; Nan, 2013; Thompson, 2008; Weber, 2005, 2008; Yusha'u, 2013; Zengin, Furkan \& Kutluca, 2012). Pupils need to comprehend various rules and procedure that cannot be expressed as algebraic formula. According to Weber (2005), pupils avoid and view Trigonometry as "a fraught with difficulty". Pupils seem have trouble reasoning Trigonometry operation.

GeoGebra is an open source software that integrates math, geometry, algebra and calculus. This software is a combination of dynamic geometry software and computer algebra system. The advantages of using GeoGebra is (1) user-friendly display, multi-language menu, instruction and help; and (2) help pupils making exploration projects; (3) various design can be make using interfaces such as font, image quality, color and others (Diković, 2009). Based on this, GeoGebra could be better alternative that could potentially help educators and pupils in T\&L. Based on past studies result, there is a huge potential of GeoGebra, such as research in the topics of probability (Radakovic, 2012), Calculus (Diković, 2009), Transformation (Kamariah Abu Bakar et al., 2010), Circle (Praveen \& Leong, 2013), Expression and Quadratic Equations (Mohd Zamri Abdullah, 2012), Function (Hutkemri Zulnaidi \& Effandi Zakaria, 2012), and Geometry coordinates ((Royati Abdul Saha, Ahmad Fauzi Mohd Ayub, \& Rohani Ahmad Tarmizi, 2010). Therefore, the objective of this study is to identify the level of motivation of under achievers pupils who underwent T\&L using GLM on the topic of Trigonometry II.

\subsection{METHODOLOGY}

This research approach is explanatory mixed method survey followed by interview of the respondent. The study examined on motivation level of pupils after undergoing T\&L Trigonometry II topic using GLM. A questionnaire adapted from Instructional Material Motivational Scale (IMMS) based on for subscale namely; Attention, Reflection Confidence and Satisfaction were given to respondent. After survey data had been analyzed, interview was held involving five pupils from the respondent.

GLM was built by researchers using GeoGebra 5.0 software. GLM consists of two main components, GeoGebraBook modules and written module. GeoGebraBook Module consists of 18 GeoGebra aplet covering revision, sinus, kosinus and tangen as well as Trigonometry function. Written module meanwhile act as giving direction and tips on how and what to explore from GeoGebraBook Module. Written module also has learning objectives, activities, exercises, and test questions.

The process of sampling is purposive sampling consist of under achiever Form Four pupils that scored an F grade in Pentaksiran Tingkatan Tiga (PT3). A total of 21 pupils from one intact class under achiever pupils were selected for this research. All of these pupils learn Trigonometry II using GLM that took two weeks' time. Pupils using GLM as self-access learning in subtopic arranged by the teacher. Pupils were allowed to explore according to subtopic assigned to them with help from teacher and fellow friend. Pupils making exploration on GeoGebraBook platform based on activities and excercises from written module. Five pupils then were selected based on purposive sampling to undergo interview by researcher.

Pupils response were coded and analyzed using means and percentages as well as independent t-test and one-way analysis of variance (ANOVA). The assumptions in using this analysis were checked beforehand. Interviews were held to obtain the views of pupils on the GLM in four subscales which are Attention, Reflection, Confidence and Satisfaction. The process of triangulation is done by comparing data from interviews and data from questionnaires.

\subsection{RESULT AND DISCUSSION}

Result from data analysis showed that the pupils have a positive motivation in T\&L Trigonometry II using GLM as shown in Table 1. Overall student motivation is high $(\mathrm{M}=4.16, \mathrm{SD}=.279)$ meanwhile, the level of motivation of pupils for each subscale in ascending order is the Confidence $(\mathrm{M}=3.92, \mathrm{SD}=.268)$, Relevant $(\mathrm{M}=4.07, \mathrm{SD}=.357)$, Attention $(\mathrm{M}=4.25, \mathrm{SD}=.320)$, and Satisfaction $(\mathrm{M}=4.50, \mathrm{SD}=$ .436).

Table 1 Motivation's level mean and standard deviation

\begin{tabular}{lcc}
\hline Subscale & Mean & Standard Deviation \\
\hline Attraction & 4.25 & .320 \\
Relevant & 4.07 & .357 \\
Confidence & 3.92 & .268 \\
Satisfaction & 4.50 & .436 \\
\hline Overall & 4.16 & .279 \\
\hline
\end{tabular}

The boys overall motivation mean $(\mathrm{M}=3.99, \mathrm{RP}=.093)$ is lower than the girls mean $(\mathrm{M}=4.26, \mathrm{RP}=0.67)$. This difference was statistically significant, [ $\mathrm{t}(19)=2,401, \mathrm{p}<0.05, \mathrm{r}=1.07]$ as shown in Table 2 . Based on ANOVA analysis carried out as shown in Table 3, significant differences exist between the two subscales which is Attention $(F(19,20)=4,705, p<.05)$ and the Relevant $(F(19.20)=5666$, p $<0.05)$. However there was no significant difference between the other two subscales of Confidence $(F(19,20)=2,572, p>0.05)$ and Satisfaction $(F(19,20)=1.68, p>0.05)$. 
Table 2 Independent t-test output for difference among gender

\begin{tabular}{ccccccccc}
\hline F & Sig. & $\mathrm{t}$ & $\mathrm{df}$ & $\begin{array}{c}\text { Sig. (2- } \\
\text { tailed) }\end{array}$ & $\begin{array}{c}\text { Mean } \\
\text { Difference }\end{array}$ & $\begin{array}{c}\text { Std. Error } \\
\text { Difference }\end{array}$ & \multicolumn{2}{c}{$\begin{array}{c}\text { 95\% Confidence Interval of the } \\
\text { Difference }\end{array}$} \\
\cline { 6 - 8 } & & & & & & Lower & Upper \\
\hline .004 & .952 & -2.401 & 19 & .027 & -.270 & .112 & -.506 & -.035 \\
\hline
\end{tabular}

Table 3 One-way ANOVA output for motivation level difference

\begin{tabular}{|c|c|c|c|c|c|c|}
\hline & & Sum of Squares & $\mathrm{df}$ & Mean Square & $\mathrm{F}$ & Sig. \\
\hline & Between Groups & .405 & 1 & .405 & 4.705 & $.043^{*}$ \\
\hline \multirow[t]{3}{*}{ Att } & Within Groups & 1.636 & 19 & .086 & & \\
\hline & Total & 2.042 & 20 & & & \\
\hline & Between Groups & .586 & 1 & .586 & 5.666 & $.028 *$ \\
\hline \multirow[t]{3}{*}{ Rel } & Within Groups & 1.965 & 19 & .103 & & \\
\hline & Total & 2.551 & 20 & & & \\
\hline & Between Groups & .171 & 1 & .171 & 2.572 & .125 \\
\hline \multirow[t]{3}{*}{ Con } & Within Groups & 1.264 & 19 & .067 & & \\
\hline & Total & 1.436 & 20 & & & \\
\hline & Between Groups & .310 & 1 & .310 & 1.680 & .210 \\
\hline \multirow[t]{2}{*}{ Sat } & Within Groups & 3.500 & 19 & .184 & & \\
\hline & Total & 3.810 & 20 & & & \\
\hline
\end{tabular}

*Att - Attention, Rel-Relevant, Con-Confidence, Sat-Satisfaction

From the interview data, in the Attention's subscale pupils view GLM as attractive and appealing. Diversity in using GLM help pupils maintain attention in the learning process. Data from the survey showed pupils learn unexpected things in this module. When interviewed, pupils have the curiosities towards Trigonometry. Aspects that attract pupils attention that can be identified is the angle animation and diversity of colors used. According to Reis (2010), the use of GeoGebra can attract pupils attraction compared to teacher-centered learning. The attention of pupils can help teachers perform effectively T\&L process.

In the Relevant subscale, pupils have positive feelings toward the importance of GeoGebra Learning Module. Pupils think GLM as important and useful modules. Examples and explanations in the written module help pupils master Trigonometry. Through interviews, the pupils see relevance of GeoGebra because pupils can control the learning process themselves. Slider function help pupils to see thorough steps in Trigonometry. Quick calculations allow pupils to examine the working requiring high cognitive load. Pupils also associate future career when describing the importance of this module.

Pupils have high confidence using GLM and stated that Trigonometry is not difficult to learn. Pupils even feel Trigonometry is easy when they first learn it using GLM. The composition of the learning material also helped pupils build confidence. When the pupils interviewed, they expressed confidence in answering post-test questions. They also informed their lack of confidence in the beginning but confidence increased afterwards. According to a study conducted by Praveen \& Leong, (2013), the pupils began to increase confidence when using GeoGebra in T\&L.

\subsection{CONCLUSION}

Pupils were found to have positive motivation towards the use of GLM in the T\&L Trigonometry II, Thus, demonstrating the potential use of the GLM among low achieving pupils. This study provides recommendations to encourage the use of mathematic dynamic software such as GeoGebra in the T\&L of mathematics as it can motivate pupils. Self access learning module that was well built using ARCS model has the ability to attract pupils' motivation to learn mathematics at pupils' own pace. Mathematics teacher should pay extra attention to boys as result shown boys have lower motivation in attention and relevant subscale compared to girls.

This positive finding on the usage of GeoGebra is consistent with studies conducted that measure motivation level in a variety of mathematical topics such as the topic of Circle (Praveen \& Leong, 2013), Quadratic Equation and Function (Mohd Zamri Abdullah, 2012), Calculus (Diković, 2009), Transformation (Kamariah Abu Bakar et al., 2010), Geometry Coordinate (Royati Abdul Saha et al., 2010), and Probability (Radakovic, 2012).

\section{Acknowledgement}

This study was funded by research grant from Universiti Pendidikan Sultan Idris Education Research Lab (2014-0096-109-33).

\section{References}

Abu-Obaidah et al. (2012). Teachers' ICT Skills and ICT Integration in the Classroom: The Case of Vocational and Technical Teachers in Malaysia. Scientific Research, 3(December), 70-76. doi:10.4236/ce.2012.38b016

Ahmad Fauzi Mohd Ayub, Rohani Ahmad Tarmizi, Kamariah Abu Bakar, \& Wong, S. L. (2014). Adoption of Wxmaxima Software in the Classroom : Effect on Students ' Motivation and Learning of Mathematics. Malaysian Journal of Mathematical Science, 8(2), 311-323.

Al-A'ali, M. (2008). A Study of Mathematics Web-Based Learning in Schools. American Journal of Applied Sciences. doi:10.3844/ajassp.2008.1506.1517 
Azura Ishak, Zakaria Kasa, Mohd Hasan Selamat, \& Bahaman Abu Samah. (2009). Perbandingan Pengajaran Berasaskan Multimedia dan Tradisional ke Atas Pencapaian Matematik dan Sikap Matematik di Kalangan Pelajar Berisiko. Jurnal Teknologi Maklumat \& Multimedia, 5, 79-89.

Demir, O. (2012). Students' Concept Development And Understanding of Sine And Cosine Functions. Universiteit van Amsterdam. Retrieved from http://www.science.uva.nl/onderwijs/thesis/centraal/files/f107257570.pdf

Diković, L. (2009). Applications Geogebra into Teaching Some Topics of Mathematics at The College Level. Computer Science and Information Systems, 6, 191-203. doi:10.2298/CSIS0902191D

Effandi Zakaria, \& Lee, L. S. (2012). Teachers 'Perceptions Toward the Use of GeoGebra in the Teaching and Learning of Mathematics. Journal of Mathematics and Statistics, 8(2), 253-257.

Escuder, A., \& M. Furner, J. (2011). The Impact of Geogebra in Math Teacher's Professional Development. In International Conference on Technologies in Collegiate Mathematics (pp. 76-84). Norfolk, USA: Department of Mathematics and Statistics Old Dominion University.

Furner, J., \& Berman, B. (2005). Confidence in Their Ability to Do Mathematics, The Need to Eradicate Math Anxiety so Our Future Students can Succesfully Compete in a High-Tech Globally Competitive World. Dimensions in Mathematics.

García, M. del M., \& Romero, I. (2009). The Influence of New Technologies on the Evolution of Learning and Attitudes towards Mathematics in Secondary Students. Electronic Journal of Research in Educational Psychology, 7, 369-395.

Gur, H. (2009). Trigonometry Learning. New Horizon in Education, 57(1), 67-80.

Hutkemri Zulnaidi, \& Effandi Zakaria. (2012). The Effect of Using GeoGebra on Conceptual and Procedural Knowledge of High School Mathematics Students. Asian Social Science, 8(11). doi:10.5539/ass.v8n11p102

Ignacio, N. G., Nieto, L. J. B., \& Barona, E. G. (2006). The affective domain in Mathematics Learning. International Electronic Journal of Mathematics Education, 1, $16-32$.

Jaworski, B. (2010). Challenge and Support in Undergraduate Mathematics for Engineers in a Geogebra Medium. MSOR Connections, 10(1).

Kamariah Abu Bakar, Ahmad Fauzi Mohd Ayub, Wong, S. L., \& Rohani Ahmad Tarmizi. (2010). Exploring Secondary School Students' Motivation Using Technologies in Teaching and Learning Mathematics. Procedia - Social and Behavioral Sciences, 2(2), 4650-4654. doi:10.1016/j.sbspro.2010.03.744

Marzita Puteh, \& Rohaidah Masri. (2006). Geometer Sketchpad: Penggunaannya dalam Pembelajaran Matematik Tambahan. Menanggapi Keberkesanan Dan Perubahan, 101-115.

Mislina Atan. (2010). A Study of Students' Perception Of Mobile Learning In Probability Lessons. Multimedia University Malaysia.

Mohd Zamri Abdullah. (2012). Kesan Penggunaan Perisian Geogebra Ke Atas Motivasi dan Pencapaian Pelajar. Universiti Kebangsaan Malaysia.

Moore, K. C. (2012). Coherence, Quantitative Reasoning, and the Trigonometry of Students. Quantitative Reasoning and Mathematical Modeling, 75-92. Retrieved from www.uwyo.edu/wisdome/_files/documents/moore.pdf

Nan, C. İ. (2013). Influence of the Constructivist Learning Approach on Students 'Levels of Learning Trigonometry and on Their Attitudes Towards Mathematics. Hacettepe University Journal of Education, 28(3), 219-232.

Noor Shah Saad, \& Sazelli Abdul Ghani. (2010). Teaching Mathematics in Secondary School : Theories and Practices (Cetakan Ke.). Tanjung Malim: Universiti Pendidikan Sultan Idris.

OECD. (2014). PISA 2012 Results in Focus. Retrieved from www.oecd.org/pisa

Praveen, S., \& Leong, K. E. (2013). Effectiveness of Using Geogebra on Students ' Understanding in Learning Circles. The Malaysian Online Journal of Educational Technology, 1(4), 1-11.

Radakovic, A. \& N. (2012). Teaching probability by using geogebra dynamic tool and implemanting critical thinking skills. Procedia - Social and Behavioral Sciences 46, 46(Galotti 1989), 4943-4947. doi:10.1016/j.sbspro.2012.06.364

Royati Abdul Saha, Ahmad Fauzi Mohd Ayub, \& Rohani Ahmad Tarmizi. (2010). The Effects of GeoGebra on Mathematics Achievement: Enlightening Coordinate Geometry Learning. Procedia - Social and Behavioral Sciences, 8, 686-693. doi:10.1016/j.sbspro.2010.12.095

Sherman, M. (2011). An Examination Of The Role Of Technological Tools In Relation To The Cognitive Demand Of Mathematical Tasks In Secondary Classrooms. University of Pittsburgh.

Thompson, P. W. (2008). Conceptual Analysis Of Mathematical Ideas: Some Spadework At The Foundation Of Mathematics Education. In Annual Meeting of the International Group for the Psychology of Mathematics Education (Vol. 1, pp. 31-49). Retrieved from http://patthompson.net/PDFversions/2008ConceptualAnalysis.pdfm

Ting, S. H. (2013). The Use of GeoGebra Software Integrated In Teaching Circle III Topic On Form Four Student. Universiti Pendidikan Sultan Idris

Weber, K. (2005). Students' Understanding of Trigonometric Functions. Mathematics Education Research Journal, 17(3), 91-112.

Weber, K. (2008). Teaching Trigonometric Functions : Lessons Learned from Research. Connecting Research To Teaching, 102(2).

Yusha'u, M. A. (2013). Difficult Topics in Junior Secondary School Mathematics : Practical Aspect of Teaching and Learning Trigonometry. Scientific Journal of Pure and Applied Science, 2, 161-174.

Zengin, Y., Furkan, H., \& Kutluca, T. (2012). The Effect of Dynamic Mathematics Software Geogebra on Student Achievement in Teaching of Trigonometry. Procedia - Social and Behavioral Sciences, 31(2011), 183-187. doi:10.1016/j.sbspro.2011.12.038 